Agro-Science Journal of Tropical Agriculture, Food, Environment and Extension Volume 13 Number 2 May 2014 pp. 17 - 23

ISSN III9-7455

\title{
AMINO ACID PROFILE OF RAW AND BOILED SEEDS OF AFRICAN WALNUT (PLUKENETIA CONOPHORUM MUELL ARG.) FROM SOUTH-EASTERN NIGERIA
}

\author{
Udeonyia $^{1}$, O. A; *Baiyeri ${ }^{1}$, K. P., F. U. Ugese ${ }^{2}$ and $\mathrm{Aba}^{1}$, S. C. \\ ${ }^{1}$ Dept. of Crop Science, University of Nigeria, Nsukka, Enugu State, Nigeria. \\ ${ }^{2}$ Dept. of Crop Production, University of Agriculture, Makurdi, Benue State, Nigeria \\ *Author for correspondence: paul.baiyeri@unn.edu.ng
}

\begin{abstract}
Seeds of African Walnut (Plukenetia conophorum Muell Arg.) obtained from four (4) states - Enugu, Anambra, Abia, Rivers - in south-eastern Nigeria were assayed for amino acid contents of the raw and cooked seeds using High Performance Liquid Chromatography (HPLC). Results indicated significant $(p \leq 0.05)$ variation in both essential and non-essential amino acid content across locations. Among the essential amino acids, the accession from Abia had the highest arginine and lysine content; Rivers had the highest concentration of histidine and valine, while Enugu showed the highest methionine and threonine content, though statistically similar with that of Abia. Boiling significantly $(p<0.05)$ increased the amount of tryptophan, but all the other essential amino acids did not respond significantly to boiling. Among the non-essential amino acids, alaninie, asparagine, glutamine, glutamic acid and glycine responded significantly to location. Boiling reduced the quantities of cysteine and glutamic acid; but increased those of glutamine and lysine. Among the essential amino acids, only histidine and lysine were significantly $(p<0.05)$ influenced by interaction effects of location and processing such that boiling drastically reduced the levels of histidine in the seeds from Anambra and Rivers but enhanced the level of histidine in the seeds from Abia. Boiling also increased the amount of lysine in the Anambra seeds but reduced the lysine level in all the other accessions. In the case of the non-essential amino acids, asparagine, glutamine and glutamic acid responded significantly $(p<0.05)$ to interactive effect of the two factors. Principal Component Analysis (PCA) explained close to $50 \%$ of the total variability in amino acid composition, identifying arginine, asparagine, lysine, methionine, valine, glutamic acid, leucine, cysteine, threonine, alanine and isoleucine as the key amino acids for describing African walnut seeds in the south-eastern zone of Nigeria. It was clear from the study that seeds of this under-utilized forest species have full complement of the amino acids in sufficient amounts to meet the amino acid requirements of its teeming consumers.
\end{abstract}

Keywords: African walnut, Plukenetia conophorum, amino acids, south-eastern Nigeria.

\section{INTRODUCTION}

Protein as a class of food is indispensable for healthy living. The quality or nutritional status of a protein is defined by its amino acid composition (Ojiako et al., 2010). In developing countries, nutritional levels are generally low, a situation that has been aggravated by high level of poverty. As such, consumption of legumes and oilseeds which are protein rich has been recommended as an affordable means of ensuring high level protein intake by resource poor families (Singh et al., 1993). Fortunately, in many of these countries a lot of these indigenous edible legumes and oilseeds are commonly available.

http://dx.doi.org/10.4314/as.v13i2.3
In Burkina Faso, Glew et al. (1997) determined among others, the amino acid composition of 24 indigenous species and concluded that many could be relied upon to provide significant amounts of essential amino acids. The interesting thing is that these local sources of nutrients are not only fit for human consumption, but can also be exploited for the formulation of animal feeds for sustainable livestock production (Ingale and Srivastava, 2011). This has the additional advantage of reducing the cost of animal protein, with far reaching implications on overall human nutrition and well being. As stated earlier, many of these indigenous species are good sources of nutrients for human nutrition. Their 
use in the formulation of domestic foods in many developing countries has been reported (Ingale and Srivastava, 2011). However, the particular form in which these products are consumed could depend on such factors as plant species, local practice or personal preference. Reports from literature however indicate that processing method has important implication on the nutritional quality of a food material. For instance, Adedeye (2010) reported that in groundnut, cooking enhanced the levels of some amino acids while reducing that of others; roasting had a more deleterious effect on the amino acid levels. Beneficial effects of cooking on levels of some amino acids were also reported in chick pea (Abdel-Rahman, 1983).

Plukenetia conophorum, commonly called African walnut, is a perennial climber that is widely distributed throughout the humid forest zone of sub-Saharan Africa (Enujiugha, 2003). In Nigeria, it is found throughout the wet part of southern Nigeria (Amaeze $e t$ al., 2011). In the wet season when the seeds are available, they are commonly consumed throughout the region as snacks when boiled (Akpuaka and Nwankor, 2000). According to Babalola (2011), the sale of cooked nuts of African walnut, either by displaying in trays or tying in transparent polythene is common in most urban centres of southern Nigeria. Besides its use as food, the species is also highly rated in ethnomedicine where it is credited with the cure of a number of human ailments (Okafor and Okorie, 1990; Ayoola et al., 2011).

The seed of Plukenetia conophorum, on dry weight basis, has been shown to contain up to $29.09 \%$ protein and $48.9 \%$ oil (Enujiugha, 2003). This oil has various industrial uses such as production of soap, wood varnishes and paints (Egharevba et al., 2005) and can therefore be exploited for industrial use. Also, the high protein content of the nut makes it a remarkable food item that is widely consumed in the whole of southern Nigeria. Studies hitherto were based on seed samples collected from a single location. This study was therefore designed to investigate the amino acid composition of nuts of Plukenetia conophorum from four locations in south eastern Nigeria. Since the nuts are usually boiled before eating, we decided to explore the effect of this processing technique on the amino acids content of the seeds.

\section{MATERIALS AND METHODS}

Seeds of African walnut, Plukenetia conophorum, were collected from four locations in south-eastern Nigeria. The four locations were the states of Enugu, Anambra, Abia and Rivers. Sample seeds were cooked in boiling water for one hour. Both cooked and uncooked samples for analysis were sundried until stable weight was obtained. Finely ground samples were used for the analysis.

Determination of amino acids content was done at the International Institute of Tropical Agriculture (IITA), Ibadan, Nigeria, by High Performance Liquid Chromatography (HPLC) using waters 616/626 LC (HPLC) instrument. Small quantities $(0.5 \mathrm{~g})$ of the samples were weighed into a sterile furnace hydrolysis tube to which $5 \mathrm{nmols}$ of Norleucine was added and dried under a vacuum. The protein was hydrolysed by placing the tube in a vial containing $10.05 \mathrm{~N} \mathrm{HCl}$ with a small quantity of phenol. This was accomplished at $108{ }^{\circ} \mathrm{C}$ and lasted for 20-23 hours.

The hydrolysed samples were derived automatically using the water 616/626 HPLC to generate phenylthiocarbamyl (PTC) amino acid derivatives. The duration for this was 45 minutes per sample, as calibrated on the instrument. A set of standard solutions of the amino acids were prepared from Pierce Reference standards H $(1000 \mu \mathrm{mol})$ into auto-sampler crops and they were also derived. After the derivatives were obtained, a methanol solution $(1.5 \mathrm{~N})$ containing the PTC-amino acids were transferred to a narrow bore waters 616/626 HPLC system for separation.

The separation and quantification of the PTC-amino acids were done on a reverse phase (18 silica column) and the PTC chromophone were automatically and digitally detected at the wavelength of $254 \mathrm{~nm}$. The elution of the whole amino acids in the samples took 30 minutes. The buffer system used for separation was $140 \mathrm{~mm}$ sodium acetate $\mathrm{pH} 5.5$ as buffer A and 80\% acetonitrile as buffer $\mathrm{B}$. The program was run using a gradient of buffer A and buffer B concentration and ending with a $55 \%$ buffer B concentration at the end of the gradient.

The intensity of the chromatographic peak areas were automatically and digitally identified and quantified using a Dionex chromeleon data analysis system which is attached to the waters 616/626 HPLC System.

Data collected were subjected to analysis of variance (ANOVA) using GENSTAT Discovery 3 Release 7.22 DE (GENSTAT, 2008). Significant differences between means were detected by means of Fisher's least significant difference (F-LSD) procedure at 5\% probability level. Amino acid variability among the accessions was examined with principal component analysis. 


\section{RESULTS}

Main effects of location and processing on essential amino acid composition of seeds of African walnut were presented in Table 1. Location had significant ( $\mathrm{p}$ $<0.05$ ) effect on the composition of arginine, histidine, lysine, methionine, threonine and valine. The accession from Abia had the highest arginine and lysine content, while Rivers had the highest concentration of histidine and valine. Seeds from Enugu showed the highest methionine and threonine content, though statistically similar with that of Abia. Boiling significantly ( $\mathrm{p}<$ 0.05 ) increased the amount of tryptophan. All other essential amino acids did not respond significantly to boiling.
Five of the non-essential amino acids did not respond in a remarkable way to location effect while the other five did (Table 2). The non-essential amino acids that responded significantly $(\mathrm{p}<0.05)$ to location were alanine, asparagine, glutamine, glutamic acid and glycine. Abia had the highest amounts of alanine, asparagine, glutamine and glycine but seeds from Enugu were significantly $(\mathrm{p}<0.05)$ higher in glutamic acid compared to other locations. Unlike what obtained in the essential amino acids, boiling elicited more significant responses in the non-essential amino acids. Thus while boiling reduced the quantities of cysteine and glutamic acid, it increased those of glutamine and glycine.

Table 1: Main effect of location and processing on essential amino acid content ( $\mathrm{g} / 100 \mathrm{~g}$ protein) of seeds of African walnut from south eastern Nigeria

\begin{tabular}{|c|c|c|c|c|c|c|c|c|c|c|}
\hline Treatment & Arginine & Histidine & Isoleucine & Leucine & Lysine & Methionine & $\begin{array}{l}\text { Phenyl } \\
\text { alanine }\end{array}$ & Threonine & Tryptophan & Valine \\
\hline \multicolumn{11}{|l|}{ Location } \\
\hline Enugu & 0.11 & 0.79 & 0.79 & 1.89 & 1.04 & 0.93 & 0.84 & 1.73 & 0.88 & 1.28 \\
\hline Anambra & 0.33 & 0.39 & 1.34 & 1.68 & 1.52 & 0.32 & 0.68 & 0.86 & 1.72 & 0.58 \\
\hline Abia & 0.92 & 0.45 & 1.22 & 2.35 & 2.20 & 0.11 & 0.86 & 1.02 & 1.22 & 0.44 \\
\hline Rivers & 0.04 & 1.09 & 0.79 & 1.83 & 0.16 & 0.59 & 0.47 & 0.66 & 1.14 & 1.55 \\
\hline LSD (0.05) & 0.53 & 0.45 & NS & NS & 0.68 & 0.47 & NS & 0.71 & NS & 0.53 \\
\hline \multicolumn{11}{|l|}{ Processing } \\
\hline Boiled & 0.38 & 0.59 & 0.90 & 1.56 & 1.16 & 0.38 & 0.71 & 1.06 & 1.51 & 0.93 \\
\hline Fresh & 0.38 & 0.78 & 1.18 & 2.32 & 1.30 & 0.59 & 0.72 & 1.02 & 0.97 & 0.99 \\
\hline $\operatorname{LSD}_{(0.05)}$ & NS & NS & NS & NS & NS & NS & NS & NS & 0.45 & NS \\
\hline
\end{tabular}

Table 2: Main effect of location and processing on non-essential amino acid content (g/100g protein) of seeds of African walnut from south eastern Nigeria

\begin{tabular}{|c|c|c|c|c|c|c|c|c|c|c|}
\hline Treatment & Alanine & Asparagine & Aspartic acid & Cysteine & Glutamine & $\begin{array}{l}\text { Glutami } \\
\mathrm{c} \text { acid }\end{array}$ & Glycine & Proline & Serine & Tyrosine \\
\hline \multicolumn{11}{|l|}{ Location } \\
\hline Enugu & 1.27 & 0.35 & 0.23 & 0.29 & 1.29 & 1.25 & 1.28 & 0.53 & 1.29 & 1.08 \\
\hline Abia & 2.28 & 1.90 & 0.09 & 0.17 & 3.87 & 0.43 & 2.07 & 1.15 & 1.33 & 0.80 \\
\hline Rivers & 1.24 & 0.20 & 0.37 & 0.24 & 0.43 & 0.16 & 1.08 & 0.55 & 1.10 & 1.22 \\
\hline $\operatorname{LSD}(0.05)$ & 1.00 & 0.73 & NS & NS & 0.98 & 0.64 & 0.89 & NS & NS & NS \\
\hline \multicolumn{11}{|l|}{ Processing } \\
\hline Boiled & 1.70 & 1.06 & 0.29 & 0.10 & 2.06 & 0.30 & 1.68 & 0.74 & 1.27 & 0.98 \\
\hline Fresh & 1.14 & 0.76 & 0.23 & 0.30 & 1.34 & 1.02 & 1.25 & 0.87 & 1.23 & 0.87 \\
\hline $\operatorname{LSD}_{(0.05)}$ & $\mathrm{NS}$ & NS & NS & 0.18 & 0.69 & 0.46 & 0.63 & NS & NS & NS \\
\hline
\end{tabular}


Interaction effect of accession and processing on essential amino acid content of African walnut seeds is presented in Table 3. Only histidine and lysine responded significantly $(\mathrm{p}<0.05)$ to the combined effects of the two factors. Boiling drastically reduced the levels of histidine in the seeds from Anambra and Rivers and only marginally reduced those of Enugu. It however enhanced the level of histidine in the seeds from Abia. On the other hand, boiling increased the amount of lysine in the Anambra seeds but reduced the lysine content of all the other accessions.

The interaction effects of location and processing on the non-essential amino acids content of African walnut seeds showed non-significant effect on all the amino acids except asparagine, glutamine and glutamic acid (Table 4). While boiling enhanced the levels of asparagine in the seeds from Enugu and Anambra, it reduced the level in seeds from Abia. Boiled seeds from Abia, Anambra and Rivers registered higher values of glutamine in contrast to those from Enugu. Levels of glutamic acid were higher in fresh raw seeds from Enugu and Anambra, while they were comparatively lower in the seeds from the other two accessions.

Table 3: Interaction effect of location and processing on essential amino acid content (g/100g protein) of seeds of African walnut from south eastern Nigeria

\begin{tabular}{|c|c|c|c|c|c|c|c|c|c|c|c|}
\hline Location & Processing & Arginine & Histidine & Isoleucine & $\begin{array}{l}\text { Leucin } \\
\mathrm{e}\end{array}$ & Lysine & Methionine & $\begin{array}{l}\text { Phenyl } \\
\text { alanine }\end{array}$ & $\begin{array}{l}\text { Threonin } \\
\mathrm{e}\end{array}$ & Tryptophan & Valine \\
\hline \multirow[t]{2}{*}{ Enugu } & Boiled & 0.16 & 0.76 & 0.71 & 1.47 & 0.73 & 0.72 & 0.73 & 1.70 & 0.90 & 1.57 \\
\hline & Fresh & 0.07 & 0.83 & 0.87 & 2.32 & 1.36 & 1.13 & 0.96 & 1.76 & 0.85 & 0.98 \\
\hline \multirow[t]{2}{*}{ Anambra } & Boiled & 0.43 & 0.21 & 1.03 & 1.51 & 2.34 & 0.18 & 0.82 & 0.89 & 2.31 & 0.26 \\
\hline & Fresh & 0.24 & 0.57 & 1.66 & 1.85 & 0.71 & 0.46 & 0.54 & 0.84 & 1.14 & 0.90 \\
\hline \multirow[t]{2}{*}{ Abia } & Boiled & 0.68 & 0.71 & 1.02 & 1.73 & 1.49 & 0.01 & 0.83 & 0.82 & 1.48 & 0.33 \\
\hline & Fresh & 1.16 & 0.19 & 1.41 & 2.97 & 2.91 & 0.22 & 0.90 & 1.22 & 0.96 & 0.55 \\
\hline \multirow[t]{2}{*}{ Rivers } & Boiled & 0.05 & 0.68 & 0.82 & 1.52 & 0.09 & 0.61 & 0.47 & 0.84 & 1.34 & 1.56 \\
\hline & Fresh & 0.07 & 1.51 & 0.76 & 2.14 & 0.22 & 0.57 & 0.47 & 0.47 & 0.95 & 1.53 \\
\hline $\operatorname{LSD}_{(0.05)}$ & & NS & 0.616 & NS & NS & 0.958 & NS & NS & NS & NS & NS \\
\hline
\end{tabular}

Table 4: Interaction effects of location and processing on non- essential amino acids content (g/100g protein) of seeds of African walnut from south eastern Nigeria

\begin{tabular}{|c|c|c|c|c|c|c|c|c|c|c|c|}
\hline Location & Processing & Alanine & Asparagine & $\begin{array}{l}\text { Aspartic } \\
\text { acid }\end{array}$ & $\begin{array}{l}\text { Cystein } \\
\mathrm{e}\end{array}$ & Glutamine & $\begin{array}{l}\text { Glutamic } \\
\text { acid }\end{array}$ & Glycine & Proline & Serine & $\begin{array}{l}\text { Tyrosi } \\
\text { ne }\end{array}$ \\
\hline \multirow[t]{2}{*}{ Enugu } & Boiled & 1.64 & 0.57 & 0.27 & 0.05 & 0.80 & 0.50 & 1.78 & 0.43 & 1.39 & 0.73 \\
\hline & Fresh & 0.90 & 0.14 & 0.19 & 0.52 & 1.77 & 2.01 & 0.78 & 0.64 & 1.19 & 1.43 \\
\hline \multirow[t]{2}{*}{ Anambra } & Boiled & 0.91 & 1.99 & 0.24 & 0.06 & 1.52 & 0.18 & 1.47 & 0.70 & 1.73 & 0.79 \\
\hline & Fresh & 0.84 & 0.36 & 0.44 & 0.16 & 0.88 & 1.44 & 1.56 & 1.27 & 0.81 & 0.42 \\
\hline \multirow[t]{2}{*}{ Abia } & Boiled & 2.47 & 1.42 & 0.10 & 0.10 & 5.42 & 0.37 & 2.75 & 1.22 & 1.06 & 0.77 \\
\hline & Fresh & 2.08 & 2.38 & 0.08 & 0.20 & 2.33 & 0.49 & 1.39 & 1.08 & 1.60 & 0.82 \\
\hline \multirow[t]{2}{*}{ Rivers } & Boiled & 1.75 & 0.25 & 0.55 & 0.18 & 0.48 & 0.17 & 0.72 & 0.59 & 0.89 & 1.64 \\
\hline & Fresh & 0.72 & 0.15 & 0.18 & 0.29 & 0.38 & 0.16 & 1.45 & 0.50 & 1.32 & 0.79 \\
\hline $\mathrm{LSD}_{(0.05)}$ & & NS & 1.03 & NS & NS & 1.38 & 0.91 & NS & NS & NS & NS \\
\hline
\end{tabular}


Table 5: Eigen vector values of amino acids from seeds of African walnut in south eastern

\begin{tabular}{|c|c|c|c|}
\hline Amino acid & PRIN 1 & PRIN 2 & PRIN 3 \\
\hline Alanine & -0.23080 & 0.00216 & -0.43461 \\
\hline Arginine & -0.34728 & 0.03718 & -0.09927 \\
\hline Asparagine & -0.34794 & 0.02917 & 0.21656 \\
\hline Aspartic acid & 0.18846 & -0.32256 & 0.10508 \\
\hline Glutamine & -0.30568 & 0.10541 & -0.23206 \\
\hline Glutamic acid & 0.07701 & 0.36126 & 0.04853 \\
\hline Glycine & -0.25924 & -0.13453 & -0.35595 \\
\hline Histidine & 0.23150 & 0.01337 & -0.32227 \\
\hline Isoleucine & -0.09497 & 0.04022 & 0.51105 \\
\hline Leucine & -0.09518 & 0.36589 & 0.04052 \\
\hline Lysine & -0.33434 & 0.25469 & 0.12981 \\
\hline Methionine & 0.30773 & 0.28451 & -0.04069 \\
\hline Phenylanine & -0.09877 & 0.11259 & 0.05752 \\
\hline Proline & -0.15790 & -0.19652 & 0.08909 \\
\hline Serine & -0.09610 & 0.07955 & 0.11190 \\
\hline Cysteine & 0.12325 & 0.38118 & -0.06947 \\
\hline Tryptophan & -0.18994 & -0.07105 & -0.21088 \\
\hline Tyrosine & 0.13368 & 0.29855 & -0.29729 \\
\hline Valine & 0.32820 & -0.14882 & -0.08944 \\
\hline threonine & 0.06360 & 0.36507 & 0.07606 \\
\hline Latent roots & 4.802 & 2.760 & 2.206 \\
\hline $\begin{array}{l}\text { Percentage of total variation } \\
\text { explained }\end{array}$ & 24.01 & 13.80 & 11.03 \\
\hline
\end{tabular}

Variability in amino acid composition of seeds from the study area as examined with principal components analysis (PCA) is shown in Table 5. The PCA result explained only about $50 \%$ of the total variability with the first, second and third principal axes explaining $24.01 \%, 13.80 \%$ and $11.03 \%$ of the total variability, respectively.

Going by the latent roots, the first principal axis (PRIN 1) identified five (5) amino acids including arginine, asparagine, lysine, methionine and valine to contribute about $24 \%$ of the total variability existing among the accessions. The second principal axis (PRIN 2) identified four other amino acids (glutamic acid, leuccine, cysteine and threonine) contributing about $14 \%$ of the amino acid variability among the accessions, whereas PRIN 3 axis identified that alanine and isoleucine contributed about $11 \%$ of the total variation. Consequently, eleven (11) amino acids including arginine, asparagine, lysine, methionine, valine, glutamic acid, leucine, cysteine, threonine, alanine and isoleucine were identified as the key amino acids for describing African walnut seeds in the south eastern zone of Nigeria.

\section{DISCUSSION}

It is probable that differences in amino acid content of provenances could be as a result of the genetic factor (Meredith and Gaskin, 1984). In seeds of the family Brassiceae, variation in amino acid and protein content has been partly linked with the relative proportions of protein fractions in the seeds (Mossé and Baudet, 1983). Bell et al. (2000) in their study involving seeds of Brassica and Sinapis species found that cultivars with higher levels of crude protein did not necessarily contain higher amounts of particular amino acids, an observation they attributed to variations in the nonprotein nitrogen (NPN) content of the samples. In this study, amino acid values were found to differ across locations even though crude protein content of the accessions, as contained in another report (Baiyeri et al., submitted for publication), were found to be statistically the same. It is likely that differences in the amounts of non-protein nitrogen and relative composition of protein fractions might account for this amino acid variability. This however were not tested but could form an important component of further investigations.

Apart from the above, soil fertility could influence amino acid distribution (Bell et al., 2000). This has been amply demonstrated by Thanapornpoonspong et al. (2005) in a study involving Amaranthus species and Chemopodium quinoa. Different rates of nitrogen were found to influence the protein fractions and amino acid content of the two species. Thus in general, higher rates of nitrogen reduced lysine and increased arginine content in the seeds. Similarly, sulphur fertilization of winter wheat increased the amino acid content of the sulphur containing amino acids - cysteine, methionine, threonine and lysine - in magnitudes ranging from 7.7 to $35.3 \%$ (Järvan et al., 2008). In the sampled location, uniformity in fertility status of the soil cannot be guaranteed and could possibly account for differences in amino acid distribution of the accessions. In the 
report of Bell et al. (2000), environment rather than genetics, was more highly implicated in observed differences in amino acid composition of tested species.

Boiling of seeds of African walnut increased or decreased the levels of some amino acids while others were not affected to any marked degree. This result is comparable to reports in groundnuts (Arachis hypogaea) where dry cooking enhanced the levels of asparagine, serine, glutamine, proline, arginine, alanine, cysteine, valine, leucine and phenylalanine, while depressing those of lysine, hystidine, threonine, methionine and isoleucine (Adeyeye, 2010). On the contrary, Ojiako et al. (2010) reported that boiling significantly reduced the protein and amino acid content of seed flours of African yam bean (Sphenostylis stenocarpa), sesame (sesamum indicum), Calabash nutmeg (Monodora myristica) and African oak (Afzelia africana). Similarly, cooking for 1 or 2 hours reduced significantly the concentrations of lysine, histidine, arginine and tryptophan in chickpea (Abdel-Rahman, 1983).

A closer look at the data in Table 1 would reveal that even though boiling enhanced the quantities of tryptophan in the seeds, in the rest of the other essential amino acids this was not so. Although, amino acid levels were not significantly affected, boiling showed a strong tendency to depress the values. In the case of the non-essential amino acids, the picture was different as boiling tended to enhance amino acid levels of the seeds. Since essential amino acids are not synthesized by the body and therefore considered indispensable, such marginal reductions may not be wholly ignored. It might be worthwhile considering the intensity or duration of cooking on essential amino acid content of the seeds of this species. In chick pea, cooking beyond one hour depressed amino acid and vitamin content of the seeds (Abdel-Rahman, 1983). It therefore appears that effect of cooking on amino acid content is highly dependent on the species concerned.

The presence of anti-nutritional factors in oilseeds tends to limit their nutritional value or utilization (Enujiugha, 2003). In African walnut, considerable amounts of these factors (oxalates, phytates and tannins) have been detected (Enujiugha and AyodeleOni, 2003). Fortunately, cooking was found to drastically reduce the concentrations of phytates and tannins in the seeds to levels that did not constitute any danger to consumers (Enujiugha, 2003). Thus the practice of boiling African walnut seeds before eating, could serve to reduce the levels of these chemical entities that limit the food value of the nuts.

On the whole, it is remarkable that seeds of this species have the full complement of both essential and nonessential amino acids as earlier reported (Gbadamosi et al., 2012). This means that conophor nut, as the species is also called, has the capacity to meet the amino acid requirement of both rural and urban dwellers who consume the nut, particularly those in the southern part of the country. When compared with amino acid values of cultivated oilseeds, this species shows impressive rating. For instance, amino acid values of cultivars of sunflower and groundnut as reported by Ingale and Shrivastava (2011) do not seem to be superior to those of conophor nut except in one or two cases. This is plausible considering the fact that Plukenetia conophorum is yet a neglected species (Gbadamosi et al., 2012), with a dearth of scientific intervention in form of genetic improvement and/or improved agronomic practices. On the contrary, the oilseed crops cited above have enjoyed several improvement interventions over the years. This is a reinforced conviction that this forest species has great potentials for utilization as a food and industrial crop.

Evidence from the present study suggests that location has considerable effects on amino acid profile of African walnut seeds in south eastern Nigeria. Boiling enhanced the levels of only tryptophan among the essential amino acids while its effect on the rest was not significant. However, the concentration of a number of the non-essential amino acids in the seeds were either enhanced or depressed by boiling. It is remarkable from the study that conophor nuts have full complement of the essential and non-essential amino acids in sufficient amounts to meet the nutritional needs of the large population that consume the nuts.

\section{REFERENCES}

Abdel- Rahman, A. Y. (1983) Effect of cooking on tryptophan, basic amino acids, protein solubility and retention of some vitamins in two varieties of chick pea. Food Chemistry 11: 139-143.

Adedeye, E. I. (2010) Effect of cooking and roasting on the amino acid composition of raw groundnut (Arachis hypogaea) seeds. Acta Sci. Pol. Technol. Aliment. 9: 201-216.

Akpuaka, M. U. and Nwankor, E. (2000) Extraction, analysis and utilization of drying-oil from Tetracarpidium conophorum. Bioresour. Technol., 73:195-196.

Ayoola, P. B., Adeyeye, A., Onawumi, O. O. and Faboya, O. O. (2011) Phytochemical and nutrient evaluation of Tetracarpidium conophorum (Nigerian walnut) root. IJRRAS 7: 197-202.

Babalola, F.D. (2011) Cultivation of African walnut Tetracarpidium conophorum mull. (arg) on agricultural plantation: an approach to conservation agriculture in Nigeria. 5th World Conference on Conservation Agriculture and $3^{\text {rd }}$ Farming Systems Design 
(WCCA/FSD), Brisbane, Australia from 2629 September 2011. pp 180-181.

Bell, J. M., Rakow, G. and Downey, R. K. (2000) Comparisons of amino acid and protein levels in oil-extracted seeds of Brassica and Sinapis species, with observations on environmental effects. Canadian Journal of Animal Science 80: 169-174.

Enujiugha, V. N. (2003) Chemical and functional characteristics of conophor nut. Pakistan Journal of Nutrition 2: 335-338.

Enujiugha, V. N. and Ayodele-Oni, O. (2003) Evaluation of nutrients and anti-nutrients in some lesser known under-utilized oilseeds. Int. Journal of Food Science and Technology 38: 525-528.

Gbadamosi, S. O., Abiose, S. H. and Aluko, R. E. (2012) solubilisation, amino acid composition and electrophoretic characterization of Conophor nut (Tetracarpidium conophorum) proteins. International Food Research Journal 19: 651-656.

GENSTAT (2008). Genstat 7.22.0 Release 3 DE Discovery Edition, Lawes Agricultural Trust, Rothmanisted Experimental Station, UK.

Glew, R. H., Vanderjagt, D. J., Lockett, C., Grivetti, L. E., Smith, G. C., Pastuszyn, A. and Millson, M. (1997) Amino acid, fatty acid and mineral composition of 24 indigenous plants of Burkina Faso. Journal of Food Composition and Analysis 10:205-217.

Ingale, S. and Shrivastava, S. K. (2011) Amino acid profile of some new varieties of oil seeds. Advanced Journal of Food Science and Technology 3: 111-115.

Järvan, M., Edesi, L., Adamson, A., Lukme, A. and Akk, A. (2008) The effect of sulphur fertilization on yield, quality of protein and baking properties of winter wheat. Agronomy Research 6: 459-469.

Meredith, F. I. and Gaskin, M. H. (1984) Effect of fertilizer nitrogen and Simazine on amino acids and proteins in Brassica. Hort. Sci. 19: 879-881.
Mossé, J. and Baudet, J. (1983) Crude protein content and amino acid composition of seeds: variability and correlations. Qual. Plant. Plant Foods Hum. Nutr. 32: 225-245.

Ojiako, O. A., Igwe, C. U. Agha, N. C., Ogbuji, C. A. and Onwuliri, V. A. (2010) Protein and amino acid compositions of Sphenostylis stenocarpa, Sesamum indicum, Monodora myristica, and Afzelia Africana seeds from Nigeria. Pakistan Journal of Nutrition 9: 368-372.

Okafor, J. C. and Okorie, P. E. (1990) Environmental and ethnobotanical importance of the tropical rainforest in Nigeria. Proc. $4^{\text {th }}$ Annual Conference of the Botanical Society of Nigeria, Nsukka.

Singh, U., Rao, V. P., Subrahmanuam, N. and Serxena, K. (1993) Cooking, chemical composition and protein quality of newly developed genotypes of pigeon pea (Cajanus cajan L.). Journal of the Science of Food and Agriculture 61: 395-400.

Thanapornpoonpong, S., Vearasilp, S., Pawelzik, E. and Gorinstein, S. (2005) Protein fractions and their amino acid composition of pseudocereals related to nitrogen supply. In: C. J. Li (ed) Plant Nutrition for Food Security, Human Health and Environmental Protection, Tsinghua University press, Beijing, China, 422-423Pp. 